\title{
Hans Arneson, Emanuel Fiano, Christine Luckritz Marquis, Kyle Richard Sмiтн (eds.), The History of the Great Deeds of Bishop Paul of Qentos and Priest John of Edessa (Piscataway, NJ: Gorgias Press, 2010) (Texts from Christian Late Antiquity Series, vol. 29) x, 87 p. ISSN 1935-6846, no ISBN.
}

This small book, the result of a graduate seminar led by Lucas Van Rompay in 2006, presents a hitherto little known work of West Syrian hagiography - a work that is both very specific and very important. It is, moreover, a work with an unlucky scholarly history: it was prepared for publication by its discoverer, François Nau, in about 1907 but, for unknown reasons, it was never published and Nau's work has been lost. The present booklet, dedicated to Nau's memory, contains a critical edition of the Syriac text, an English translation with commentary, and a study by Kyle Smith published as the Introduction (almost identical to his previous paper in Hugoye, 2009). The terminus ante quem of the text is defined by the date of the earliest manuscript, A.D. 568/569. A portion of the text is known in the unique Greek manuscript published by A. Papadopoulos-Kerameus in 1898 (BHG 1476).

The History of Bishop Paul and Priest John is a hagiographical novel whose main character is Paul, a secret bishop who left his native town in Italia almost immediately after his consecration and spent the rest of his life as a wanderer in Syria, Palestine, Sinai, and the Arabian Peninsula. Priest John became his friend and companion.

In his study, Kyle Smith follows Sebastian Brock's view (2003) that the original language of the piece is Syriac. Thus, following both Brock and Nau, he accepts that Paul's place of origin and the name of his see should be read as a town in Italia named Qnțws and not a town in Attalia named "Pontos," as the Greek version states. In Syriac, there are also some manuscripts which read "Pontos" ( $p$ and $q$ being very similar in Syriac writing), whereas "Attalia" and "Italia" are completely indistinguishable in Syriac writing. There is, at any rate, certainly no manuscript that provides a clear and realistic geography of Paul's native place. Thus, "Qnțws in Italia" is no more than the most plausible supposition. What is certain, though, is the geography of Paul's and John's travels. This is especially interesting because, according to the legend, they both became apostles of the Christian faith in Nağrān in Arabia.

Smith elaborates on the comparison, proposed by Jurgen Tubach in 1993 and Theresia Hainthaler in 2007, between this legend and a Christian legend on the conversion of Nağrān preserved by Muslim sources going back to Ibn Ishāa, the eighth-century biographer of 
Muhammad (this legend is about a pair of missionaries in Nağrān named Fymywn and Șalih). I have revisited this matter elsewhere [B. Lourié, Friday Veneration in Sixth- and Seventh-Century Christianity and Christian Legends about the Conversion of Nağrān, in: B. Lourié, C. A. Segovia (eds.), The Coming of the Comforter: When, Where, and to Whom? Studies on the Rise of Islam and Various Other Topics in Memory of John Wansbrough (Piscataway, NJ, 2011) (Orientalia Judaica Christiana, 3)]. I came to the conclusion that all the motives and episodes of the Fymywn legend have their prototypes in the Syriac text. The ordering of the episodes is also the same but with a unique exception: in the Syriac text, the meeting of Paul and John with the dendrite (an anchoret who lived on the branches of a tree; this kind of asceticism emerged in Syria at the same epoch as stylitism, in the fifth century) takes place not on their way to Nağrān but after their Arabian mission. Thus, despite the difference in proper names, one has to conclude that, in both cases, we are dealing with the same legend. The dendrite is an object of specific attention in Smith's study.

Unlike Tubach, Smith does not overstress the similarities between the present Syriac legend and the Syriac legend about Alexis, Man of God. He notices, however, not only certain intertextual connexions, but also the fact that the plot of the legend is developed (anachronistically, even if Paul and John are purely legendary figures) under the bishop of Edessa Rabbula (411-435), which makes Paul and John contemporaries of the Man of God. The legend of the Man of God is certainly important for the hagiographical substrate of the legend of Paul and John, but the latter is not a derivate of the former.

The publication of the legend of Paul and John opens the way for the realisation of another project following François Nau's scholarship. In his 1908 article "Hagiographie syriaque," where he described for the first time the legend of Paul and John, Nau also described another unpublished legend about the secret bishop John and the personified Friday. The two legends have several important common features, including the unusual reference to the veneration of Friday among the Christians. In my paper mentioned above ("Friday Veneration...") I have traced the mutual relationship between these two legends, on the one hand, and between both of them and early Christianity in Nağrān, on the other. Thus, we now await a critical edition and a study of the legend about Bishop John and the personified Friday. The present study of the legend of Paul and John has prepared the way for this next step. 